\title{
Hepatitis B learning needs assessment of family medicine trainees in Canada: Results of a nationwide survey
}

\author{
Justina J Sam MD ${ }^{1}$, E Jenny Heathcote MBBS MD FRCP FRCPC ${ }^{1}$, David KH Wong MD FRCPC ${ }^{1}$, \\ Douglas L Wooster MD FRCSC FACS RVT RPVI ${ }^{2}$, Hemant Shah MD FRCPC ${ }^{1}$
}

\begin{abstract}
JJ Sam, EJ Heathcote, DKH Wong, DL Wooster, H Shah. Hepatitis B learning needs assessment of family medicine trainees in Canada: Results of a nationwide survey. Can J Gastroenterol 2011;25(3):127-134.
\end{abstract}

BACKGROUND: An estimated 350 million people worldwide have chronic hepatitis $\mathrm{B}(\mathrm{CHB})$, which is a major cause of cirrhosis and hepatocellular carcinoma.

OBJECTIVE: To assess the level of knowledge among family medicine trainees regarding the identification and management of $\mathrm{CHB}$.

METHODS: A questionnaire to assess knowledge regarding screening and management of patients with $\mathrm{CHB}$ and cirrhosis was developed. The questionnaire was pilot tested among primary care physicians, subsequently revised and distributed to family medicine trainees across Canada through an online survey program (QuestionPro).

RESULTS: A total of 158 trainees completed the questionnaire. Of these, $54 \%$ to $56 \%$ routinely offered vaccination against hepatitis A or hepatitis B virus (HBV), and $42 \%$ regularly screened patients for HBV risk factors. The percentage who recognized the need to screen highrisk populations for $\mathrm{CHB}$, ie, individuals from an HBV-endemic country, men who have sex with men, or intravenous drug users was $73 \%$, $66 \%$ and $74 \%$, respectively. While less than $50 \%$ of respondents used the appropriate HBV screening tests, $86 \%$ to $91 \%$ correctly interpreted various HBV serological patterns. Only 3\% recognized cirrhosis in our case scenario. Almost $80 \%$ of respondents inappropriately preferred prescribing a narcotic or nonsteroidal anti-inflammatory drug over acetaminophen $(4 \%)$ for pain control in a patient with cirrhosis. While less than $60 \%$ recognized $\mathrm{HBeAg}$ negative $\mathrm{CHB}$ as an indication for referral and treatment, 90\% would have referred a patient in the immune-tolerant phase, even though treatment is not indicated.

CONCLUSIONS: Knowledge gaps regarding $\mathrm{CHB}$ among family medicine trainees in the areas of primary prevention, disease recognition and management of cirrhosis were identified. Results suggest that opportunities to prevent potentially life-threatening complications are being missed.

Key Words: Chronic hepatitis B; Family medicine trainees; Provider knowledge

\section{L'évaluation des besoin d'apprentissage sur}

l'hépatite $B$ des stagiaires en médecine de famille du Canada : les résultats d'une enquête nationale

HISTORIQUE : On estime que 350 millions de personnes dans le monde sont atteintes d'hépatite $\mathrm{B}$ chronique (HBC), qui est une cause majeure de cirrhose et de carcinome hépatocellulaire.

OBJECTIF : Évaluer le taux de connaissance des stagiaires en médecine familiale au sujet du dépistage et de la prise en charge de l'HBC. MÉTHODOLOGIE : Les chercheurs ont préparé un questionnaire pour évaluer les connaissances au sujet du dépistage et de la prise en charge des patients atteints d'HBC et de cirrhose. Le questionnaire a fait l'objet d'un projet pilote chez des médecins de premier recours. Il a ensuite été révisé et distribué aux stagiaires en médecine de famille du Canada au moyen d'un programme d'enquête en ligne (QuestionPro). RÉSULTATS : Au total, 158 stagiaires ont rempli le questionnaire. De ce nombre, de $54 \%$ à $56 \%$ offraient systématiquement le vaccin contre l'hépatite $\mathrm{A}$ ou l'hépatite $\mathrm{B}(\mathrm{VHB})$, et $42 \%$ faisaient régulièrement le dépistage des facteurs de risque du VHB chez les patients. Le pourcentage qui convenait de la nécessité de faire un test de dépistage auprès des populations à haut risque de l'HBC, c'est-à-dire les personnes provenant d'un pays endémique du VHB, les hommes qui ont des relations sexuelles avec les hommes ou les consommateurs de drogues intraveineuses, s'élevait à $73 \%$, à $66 \%$ et à $74 \%$, respectivement. Tandis que moins de $50 \%$ des répondants ont utilisé les tests de dépistage du VHB pertinents, de $86 \%$ à $91 \%$ ont interprété correctement divers bilans sérologiques du VHB. Seulement $3 \%$ ont diagnostiqué une cirrhose dans notre scénario de cas. Près de $80 \%$ des répondants préféraient à tort prescrire un narcotique ou un anti-inflammatoire non stéroïdien plutôt que de l'acétaminophène ( 4 \%) pour contrôler la douleur chez un patient atteint de cirrhose. Tandis que moins de $60 \%$ savaient que l'HBC négative à l'antigène e du VHB était une indication d'aiguillage et de traitement, $90 \%$ auraient aiguillé un patient en phase immunotolérante, même si le traitement n'est alors pas indiqué.

CONCLUSIONS : Les chercheurs ont repéré des lacunes au sujet de l'HBC chez les stagiaires en médecine de famille en matière de prévention primaire, de dépistage de la maladie et de prise en charge de la cirrhose. D'après les résultats, on perd des occasions de prévenir des complications mettant en jeu le pronostic vital.

Studies indicate inadequate screening of these high-risk populations by primary care physicians (PCPs) in the United States $(6,7)$. Because most chronically infected individuals are asymptomatic even when advanced disease is present - they are usually diagnosed by their treating physician as a result of biochemical or serological testing triggered by clinical suspicion.

There are limited data assessing knowledge levels and practice patterns of PCPs concerning screening and management of $\mathrm{CHB}$ (7-9). We sought to determine the knowledge base and practice patterns of family medicine trainees across Canada regarding the management of CHB.

\footnotetext{
${ }^{1}$ Department of Medicine; ${ }^{2}$ Department of Surgery, University of Toronto, Toronto, Ontario

Correspondence: Dr Hemant Shah, Division of Gastroenterology, Toronto Western Hospital, 6B Fell, Room 153, 399 Bathurst Street, Toronto,

Ontario M5T 2S8. Telephone 416-603-5914, fax 416-603-6281, e-mail hemant.shah@utoronto.ca

Received for publication February 2, 2010. Accepted September 15, 2010
} 
TABLE 1

Baseline demographics of the respondents $(n=158)$

\begin{tabular}{lc}
\hline Variables & Respondents \\
\hline Age, years, mean \pm SD & $30 \pm 5.0$ \\
Sex, \% & \\
$\quad$ Male & 24 \\
Female & 76 \\
Patients, n with chronic hepatitis B seen per month, \% & \\
$<5$ & 97 \\
$6-10$ & 2 \\
$11-20$ & 0 \\
$>20$ & 1 \\
Level of training, \% & \\
Postgraduate year 1 & 50 \\
Postgraduate year 2 & 50 \\
Languages spoken other than English or French, \% & \\
Spanish & 7 \\
Italian & 3 \\
Chinese & 3 \\
Hindi & 2 \\
\hline
\end{tabular}

\section{METHODS}

Study population

The study population consisted of family medicine residents at all levels of training at all accredited family medicine residency programs across Canada.

\section{Survey design and content}

A questionnaire (Appendix 1A) was developed to assess the knowledge of family medicine trainees regarding screening and management of patients with $\mathrm{CHB}$ and cirrhosis. The questionnaire focused on vaccination, screening at-risk patients, diagnostic testing, recognizing and managing cirrhosis, indications for specialist referrals, and trainees' self-assessment of their current and desired knowledge of CHB. All collaborating authors reviewed the questionnaire for validity. The questionnaire was reviewed by four family physicians at the University of Toronto (Toronto, Ontario), who provided feedback on the clarity of the survey, and the comprehensiveness and appropriateness of the items and response categories. Correct responses were determined by current published guidelines $(4,10)$ and by consensus of the participating hepatologists. The questionnaire was pilot tested among PCPs during the Hepatitis Symposium at The Conference on Health Care of the Chinese in North America, held September 27, 2008, in Toronto, Ontario, and was revised and translated into French by a professional translation service (Appendix 1B).

Survey administration and data collection

The family medicine program directors at the accredited Canadian family medicine training programs were contacted in writing with a description of the present study and a request to distribute the electronic link to the survey, a cover letter and a consent form to their residents. Program directors who did not respond within two weeks received a second e-mail inviting them to participate in the study. The questionnaire was made available online through QuestionPro (a survey engine) and was administered between November 2008 and March 2009. All responses remained anonymous and were coded with a unique identification number.

\section{Outcome measures}

The main outcome measures included knowledge of risk factors and screening for $\mathrm{CHB}$, and recognition and management of cirrhosis. The secondary outcome measures included self-reported current and desired levels of knowledge regarding $\mathrm{CHB}$, and the respondents' preferred learning format.
TABLE 2

Participation according to residency program $(n=158)$

\begin{tabular}{lc}
\hline Residency program & Respondents, n \\
\hline Dalhousie University (Halifax, Nova Scotia) & 0 \\
Queen's University (Kingston, Ontario) & 17 \\
McGill University (Montreal, Quebec) & 3 \\
McMaster University (Hamilton, Ontario) & $*$ \\
Memorial University (St John's, Newfoundland and & 2 \\
Labrador) & \\
Northern Ontario School of Medicine (Sudbury, Ontario) & 6 \\
University of Alberta (Edmonton, Alberta) & 14 \\
University of British Columbia (Vancouver, British & $*$ \\
Columbia) & \\
University of Calgary (Calgary, Alberta) & 15 \\
Université Laval (St Foy, Quebec) & $*$ \\
University of Manitoba (Winnipeg, Manitoba) & 5 \\
Université de Montréal (Montréal, Québec) & 20 \\
University of Saskatchewan (Saskatoon, Saskatchewan) & 1 \\
University of Toronto (Toronto, Ontario) & 57 \\
University of Ottawa (Ottawa, Ontario) & $\dagger$ \\
Université de Sherbrooke (Sherbrooke, Quebec) & 4 \\
University of Western Ontario (London, Ontario) & 8 \\
\hline
\end{tabular}

${ }^{*}$ Declined to participate; ${ }^{\dagger}$ Delayed participation

Statistical analysis

Data were collected in an Excel 2007 spreadsheet (Microsoft Corporation, USA) using the QuestionPro software. Descriptive statistics were used to describe the responses to each question.

\section{Ethical considerations}

The research protocol was approved by the Research Ethics Boards of the University Health Network (University of Toronto) and The University of Western Ontario (London, Ontario).

\section{RESULTS}

Table 1 summarizes the demographics and characteristics of the respondents. Three programs chose not to participate (Table 2). A total of 158 family medicine residents completed the questionnaire. The estimated response rate among the programs that participated in the present study was 15\%, based on the Canadian Residents Matching Service statistics reflecting the total number of first- and second-year family medicine residents in the country at the time of the study (11). Respondents had a mean $( \pm$ SD) age of $30 \pm 5.0$ years, the majority of whom (76\%) were women. Ninety-seven per cent knowingly saw less than five patients with $\mathrm{CHB}$ per month.

\section{Vaccination}

Routine vaccination against HBV in those known to have no immunity was recommended by $54 \%$ of the respondents, while vaccination against hepatitis A virus (HAV) in CHB patients without immunity to HAV was offered by $56 \%$. Eighty-four per cent of respondents were familiar with how to protect an infant born of an HBV surface antigen (HBsAg)-positive mother (ie, by administering the HBV vaccine series and the HBV immune globulin to the newborn at birth $[3,12]$ ).

\section{Screening}

Forty-two per cent of respondents regularly asked their patients whether they had risk factors for HBV. Thirty-four per cent incorrectly believed that men who have sex with men do not require routine screening for HBV, while $27 \%$ and $26 \%$, respectively, would not routinely screen patients from an HBV-endemic country or a patient with a history of intravenous drug use (Table 3). Appropriate use of the three recommended screening tests (ie, HBsAg, anti-HBV surface antibody, antiHBV core antibody) to determine HBV status was practised by $49 \%$ of respondents. Thirty-nine per cent of respondents used HBeAg as an 
initial screening test for HBV. Between $86 \%$ and $91 \%$ correctly interpreted a variety of serological test results, which included immunity due to vaccination, previous infection with $\mathrm{HBV}$ and active ongoing infection.

\section{Recognition and management of patients with cirrhosis}

Ninety-one per cent of respondents knew that normal levels of alanine aminotransferase (ALT) did not necessarily exclude liver disease. While $81 \%$ acknowledeged that cirrhosis is often asymptomatic, $73 \%$ recognized that a normal abdominal ultrasound examination did not exclude cirrhosis. In our case scenario of an individual with $\mathrm{CHB}$ and thrombocytopenia but preserved hepatic synthetic function, $3 \%$ of respondents accurately recognized the patient's high likelihood of having cirrhosis. A total of $47 \%$ of respondents incorrectly selected a narcotic as the safest option for pain management in a cirrhotic patient, and $31 \%$ chose a nonsteroidal anti-inflammatory drug. Acetaminophen was chosen by $4 \%$ of respondents to be the safest for use in patients with liver disease.

\section{Referral to specialists}

Ninety per cent of respondents would refer a patient in the immunetolerant phase for treatment (ie, a 24-year-old woman, HBeAg positive, HBV DNA $9 \log \mathrm{IU} / \mathrm{mL}$, ALT $24 \mathrm{IU} / \mathrm{L}$ and platelets $285 \times 10^{9} / \mathrm{L}$ ), while $59 \%$ recognized $\mathrm{HBeAg}$-negative $\mathrm{CHB}$ status as an indication to consider treatment (ie, a 45-year-old man, HBeAg negative, HBV DNA $5 \log \mathrm{IU} / \mathrm{mL}$, ALT $43 \mathrm{IU} / \mathrm{L}$ and platelets $145 \times 10^{9} / \mathrm{L}$ ).

\section{Current and desired levels of knowledge}

Sixty-one per cent of respondents believed that they had moderate to high levels of knowledge concerning the recognition of cirrhosis, but $68 \%$ were not confident in managing a patient with cirrhosis. Eighty-four per cent and $77 \%$, respectively, believed that they possessed moderate to high levels of knowledge with regard to identifying risk factors for HBV and who should be screened for HBV. Overall, $65 \%$ believed that they had moderate to high levels of knowledge in interpreting screening tests for HBV. The majority (more than 90\%) wanted to learn more about $\mathrm{CHB}$ including identifying risk factors, screening, recognizing and managing cirrhosis, and screening for HCC.

\section{Sources of knowledge}

Sixty-four per cent of respondents believed that online resources were the best way to update their knowledge, $13 \%$ believed that conferences would be the preferred mode of learning and $8 \%$ would consult books or journals.

\section{DISCUSSION}

HBV has important medical, economic and social consequences, particularly among immigrants to North America. Early diagnosis of HBV is crucial because it provides the patient with the opportunity to be counselled about preventive measures to decrease the risk of transmission to others, receive preventive services, and be monitored and evaluated for therapy.

We identified knowledge gaps regarding $\mathrm{CHB}$ among family medicine trainees in several domains. The most striking areas were primary prevention (ie, vaccination in those without immunity, identification of those at risk for $\mathrm{CHB}$ and initiation of appropriate screening tests) and recognition of cirrhosis. The American Association for the Study of Liver Diseases practice guidelines (4) advise that all seronegative individuals should be vaccinated against $\mathrm{HBV}$, while patients with $\mathrm{CHB}$ who are not immune to HAV should be vaccinated against HAV. The low number of patients with $\mathrm{CHB}$ reportedly seen each month by the respondents was likely an underestimate, particularly for those practicing in major Canadian cities. In our study, 36\% and 13\% of respondents were from Toronto and Montreal (Quebec), respectively, both of which are high-density areas for immigrants. Under recognition of this chronic infection may be due to failure to screen at-risk individuals. This is consistent with another study (7) in which $91 \%$ of family physicians reportedly diagnosed five or fewer cases of $\mathrm{HBV}$ in
TABLE 3

Screening for hepatitis B virus (HBV) infection by trainees (n=158)

Individuals who were NOT routinely screened by trainees for HBV

Respondents, \%

Any individual with a history of intravenous drug abuse* 26

Hepatitis C-infected individual*

4

Any individual who received a blood transfusion before 1992

Any individual from a country with an HBV carrier rate of $\geq 2 \%$ *

All pregnant women*

Men who have sex with men*

4

27

${ }^{*}$ Guidelines recommend screening for $\mathrm{HBV}$ in these patients $(4,13)$

the previous year. Our data showed that a significant proportion of trainees did not recognize the major risk groups for $\mathrm{CHB}$ as outlined in the current guidelines $(4,13)$. By comparison, Ferrante et al (7) showed that although more than $90 \%$ of family physicians in north central New Jersey (USA) recommended screening for HBV in injection drug users and men who have sex with men, less than 70\% would screen immigrants from endemic countries (7).

It is concerning that only $3 \%$ of trainees correctly recognized cirrhosis in a patient with $\mathrm{CHB}$ and thrombocytopenia. The common misconception that it is unsafe to prescribe acetaminophen to control pain in cirrhosis was demonstrated by the fact that only $4 \%$ of respondents believed that it was safe for use, whereas almost $80 \%$ would have prescribed either a narcotic or a nonsteroidal anti-inflammatory drug, even though these medications may precipitate hepatic encephalopathy and/or the hepatorenal syndrome in an individual with cirrhosis $(14,15)$.

Although the majority of respondents would refer a patient in the immune-tolerant phase to a specialist for treatment even though therapy is currently not considered appropriate at this stage of infection (12), $43 \%$ did not recognize the need to refer a patient with $\mathrm{CHB}$ who tested negative for $\mathrm{HBeAg}$. Whereas the immune-tolerant phase in a young patient is associated with minimal liver injury, active $\mathrm{HBeAg}$ negative $\mathrm{CHB}$ is associated with progression to cirrhosis and HCC, and these patients should be assessed for treatment.

The discrepancy between trainees' self-assessment and the objective measurements of their levels of knowledge, particularly with respect to screening for $\mathrm{CHB}$ and recognizing cirrhosis, is concerning. Sixty-two per cent of respondents believed that they possessed moderate to high levels of knowledge with regard to recognizing cirrhosis, but only $3 \%$ recognized the patient with probable cirrhosis in our case scenario. While less than $50 \%$ chose the appropriate screening tests for $\mathrm{HBV}$, almost $80 \%$ of trainees were confident that their knowledge in this area was adequate.

Our study has several limitations. The overall response rate of $15 \%$ was lower than that obtained in other surveys of PCPs or residents $(7,16-20)$. Moreover, the response rate from each school was variable. Selection bias was a possibility, and residents who completed the survey may have had reason to be more interested in HBV than those who did not participate. If that was the case, then it is possible that their knowledge levels may represent the 'best-case' scenario. In retrospect, we realize that the option of answering 'I don't know' should have been offered because results from this category may have provided us with a more comprehensive assessment of trainees' knowledge levels and, possibly, would have encouraged higher participation. Our data were based on self-reports; therefore, it is not clear whether our figures reflect actual practice. However, this is the first study to evaluate knowledge levels and screening practices for HBV among family medicine trainees across Canada. Because our study was limited to residents, the results cannot necessarily be generalized to practicing family physicians, but they do suggest that HBV may be inadequately represented in the medical curricula. 
Specific educational initiatives and guidelines designed for PCPs are needed to overcome these knowledge gaps to assist them in identifying patients at risk, conducting initial diagnostic tests and initiating appropriate referrals. The majority of the trainees supported online resources as the most effective way to update their knowledge. While there are several current national and international guidelines that address the management of patients with $\mathrm{CHB}$, these guidelines can be difficult to integrate into a family physician's busy practice. Even more confusing are the differences between the treatment guidelines for $\mathrm{CHB}$ and a frequently cited expert treatment algorithm in the United States (21). To our knowledge, there are no specific guidelines on screening, monitoring, or the initial management or referral of $\mathrm{CHB}$ patients in the adult population that are targeted toward family physicians. The Public Health Agency of Canada and The College of Family Physicians of Canada published Primary Care Management of Chronic Hepatitis C: Professional Desk Reference 2009 (22), a concise clinical tool that delineates an assessment sequence for family physicians. A similar electronic resource for HBV would be equally as valuable. Moreover, in collaboration with gastroenterology and hepatology faculties, a standardized curriculum that includes an emphasis on liver diseases should be developed for family medicine trainees.

\section{CONCLUSIONS}

We identified knowledge gaps pertaining to $\mathrm{CHB}$ among family medicine trainees. The knowledge deficits demonstrated in our survey of this group may reflect suboptimal access to care for patients and suggest that opportunities to prevent potentially life-threatening complications of $\mathrm{CHB}$ are being missed. Further research assessing knowledge gaps and learning goals regarding $\mathrm{CHB}$ is necessary among family medicine trainees. In addition, a study to assess physicians in practice is warranted to determine which types of educational initiatives are most effective in creating sustainable, long-term practice changes in managing $\mathrm{CHB}$. Results from further needs assessment studies may subsequently be used to increase public awareness of HBV as an important issue, particularly as it relates to immigrant health. This needs to be addressed countrywide by the Public Health Agency of Canada. This is also an excellent opportunity for organizations such as the Canadian Association for the Study of the Liver and the Canadian Association of Gastroenterology to develop resources related to HBV that are targeted toward family physicians.

ACKNOWLEDGEMENTS: The authors thank the primary care physicians, and the family medicine program directors and trainees who participated in this study.

1. What is your gender?

\section{APPENDIX 1A HEPATITIS B QUESTIONNAIRE}

1) Male

2) Female

2. What is your age? years

3. Besides English, what other languages do you speak fluently?

4. Which university are you currently attending?

Dalhousie University

Queen's University

McGill University

McMaster University

Memorial University

Northern Ontario School of Medicine

University of Alberta
University of British Columbia

University of Calgary

Université Laval

University of Manitoba

Université de Montréal

University of Saskatchewan

University of Toronto

University of Ottawa

Université de Sherbrooke

University of Western Ontario

5. What is your level of training in family medicine?
1) PGY1
2) $P G Y 2$
3) $\mathrm{PGY3}$
4) Other

6. How many of the patients that you have seen in the past month have hepatitis $\mathrm{B}$ ?
1) $<5$
2) $5-10$
3) $11-20$
4) $>20$

7. How would you protect an infant born to an $\mathrm{HBsAg}$ positive mother? (choose all that apply)

1) Caesarean section

2) Hepatitis $B$ vaccine at birth + immunoglobulin therapy (HBIg) at birth together

3) HBIg given at birth alone

4) Hepatitis $B$ vaccine given at birth alone

5) Don't know

Correct answer: 2

8. Do you routinely consider hepatitis B vaccination for your patients?

1) Never

2) Rarely

3) Usually

4) Always

9. Do you routinely offer hepatitis A vaccination to patients with chronic hepatitis $\mathrm{B}$ who are seronegative for HAV Ab?
1) Never
2) Rarely
3) Usually
4) Always

10. Do you routinely ask your patients if they have risk factors for hepatitis $\mathrm{B}$ ?
1) Never
2) Rarely
3) Usually
4) Always

11. Who would you NOT routinely screen for hepatitis B? (choose all who apply)

1) Any individual with a history of IV drug abuse

2) Hepatitis $C$ infected individual

3) Any individual who received a blood transfusion before 1992

4) Any individual from a country with an HBV carrier rate of $\geq 2 \%$ 

5) All pregnant women
6) Men who have sex with men
Correct answer: 3

12. What 3 screening tests would you use to identify an individual's hepatitis B status?
1) ALT / AST
2) $\mathrm{HBs} \mathrm{Ag}$
3) anti-HBs
4) $\mathrm{HBe} \mathrm{Ag}$
5) anti-HBe
6) anti-HBc (total)
Correct answer: 2, 3 and 6

13. What do these serologic patterns mean?

\begin{tabular}{|l|c|c|c|}
\hline & $\begin{array}{c}\text { Immune } \\
\text { due to prior } \\
\text { vaccination }\end{array}$ & $\begin{array}{c}\text { Previous } \\
\text { infection } \\
\text { with } \\
\text { hepatitis B }\end{array}$ & $\begin{array}{c}\text { Active } \\
\text { ongoing } \\
\text { hepatitis B } \\
\text { infection }\end{array}$ \\
\hline $\mathrm{HbsAg+}+$ anti-HBs-, anti-HBc+ & & & $\mathrm{x}$ \\
\hline $\mathrm{HBsAg}-$, anti-HBs+, anti-HBc+ & & $\mathrm{x}$ & \\
\hline $\mathrm{HBsAg}-$, anti-HBs+, anti-HBc- & $\mathrm{x}$ & & \\
\hline
\end{tabular}

14. Normal ALT excludes significant liver disease
1) True
2) False
Correct answer: 2

15. Most cirrhotics are asymptomatic
1) True
2) False
Correct answer: 1

16. A normal abdominal ultrasound excludes cirrhosis
1) True
2) False
Correct answer: 2

17. A 55-year-old man with chronic hepatitis B has the following: ALT 24

Platelets 125

INR 1.0

Albumin 40

Bilirubin $17 \mathrm{micromol} / \mathrm{L}$

The chance of him having cirrhosis is:
1) Low
2) Moderate
3) High
4) Don't know
Correct answer: 3

18. In which of your chronic hepatitis B patients would you initiate regular surveillance for hepatocellular carcinoma?
1) Any individual undergoing treatment for hepatitis $B$
2) Any individual $>50$ years
3) Any individual with elevated transaminases
4) Any individual with a high viral load
5) All of the above
Correct Answer: 2

19. Which of the following is safest for pain management in a cirrhotic patient?
1) Morphine
2) Acetaminophen
3) Ibuprofen
4) Codeine
5) None of the above
Correct answer: 2

20. Would you refer this patient to a specialist to consider treatment?

24-year-old female

Platelets 285

$\mathrm{HBeAg}+$

HBV DNA $9 \log \mathrm{IU} / \mathrm{mL}$

ALT 24

1) Yes

2) $\mathrm{No}$

Correct answer: 2

21. Would you refer this patient to a specialist to consider treatment?

45-year-old male

Platelets 145

HBeAg -

HBV DNA $5 \log \mathrm{IU} / \mathrm{mL}$

ALT 43

1) Yes

2) No

Correct answer: 1

22. For each of the following topics, please rate your own CURRENT levels of knowledge.

\begin{tabular}{|c|c|c|c|c|c|}
\hline \multirow[b]{2}{*}{ Topic } & \multicolumn{5}{|c|}{ Low ........................... High } \\
\hline & 1 & 2 & 3 & 4 & 5 \\
\hline \multicolumn{6}{|l|}{ Identifying risk factors for hepatitis B } \\
\hline \multicolumn{6}{|l|}{ Screening for hepatitis B } \\
\hline \multicolumn{6}{|l|}{ Interpreting screening tests for hepatitis B } \\
\hline \multicolumn{6}{|l|}{ Vaccination in hepatitis B patients } \\
\hline \multicolumn{6}{|l|}{ Recognizing cirrhosis } \\
\hline \multicolumn{6}{|l|}{ Managing the patient with cirrhosis } \\
\hline Screening for hepatocellular carcinoma (HCC) & & & & & \\
\hline
\end{tabular}

23. For each of the following topics, please rate your own DESIRED levels of knowledge.

\begin{tabular}{|c|c|c|c|c|c|}
\hline \multirow[b]{2}{*}{ Topic } & \multicolumn{5}{|c|}{ Low ............................ High } \\
\hline & 1 & 2 & 3 & 4 & 5 \\
\hline Identifying risk factors for hepatitis B & & & & & \\
\hline Screening for hepatitis B & & & & & \\
\hline Interpreting screening tests for hepatitis B & & & & & \\
\hline Vaccination in hepatitis B patients & & & & & \\
\hline Recognizing cirrhosis & & & & & \\
\hline Managing the patient with cirrhosis & & & & & \\
\hline Screening for hepatocellular carcinoma (HCC) & & & & & \\
\hline
\end{tabular}

24. What would you consider to be the best source for you to update your knowledge on hepatitis B?

1) Journals

2) Books 

3) Online resources
4) Conferences
5) Other

\section{APPENDIX 1B}

\section{QUESTIONNAIRE SUR L'HÉPATITE B}

1. Quel est votre sexe?

1) Masculin

2) Féminin

2. Quel âge avez-vous? ans

3. À part le français, quelle(s) autre(s) langue(s) parlez-vous couramment?

4. À quelle université êtes-vous inscrit(e) à l'heure actuelle?

Dalhousie University

Queen's University

McGill University

McMaster University

Memorial University

Northern Ontario School of Medicine

University of Alberta

University of British Columbia

University of Calgary

Université Laval

University of Manitoba

Université de Montréal

University of Saskatchewan

University of Toronto

University of Ottawa

Université de Sherbrooke

University of Western Ontario

5. Combien d'années de formation avez-vous suivies en médecine familiale?
1) PGY-1
2) $P G Y-2$
3) PGY-3
4) Autre

6. Parmi les patients que vous avez vus le mois dernier, combien étaient atteints d'hépatite $B$ ?
1) $<5$
2) 5 à 10
3) 11 à 20
4) $>20$

7. Que feriez-vous pour protéger un enfant à naître dont la mère est positive pour l'AgHBs? (Choisissez toutes les réponses qui s'appliquent.)

1) Césarienne

2) Administration d'un vaccin contre l'hépatite $B$ et d'immunoglobuline (HBIg) à la naissance

3) Administration d'HBIg à la naissance

4) Administration d'un vaccin contre l'hépatite $B$ à la naissance

5) Je ne sais pas

Réponse correcte: 2
8. Songez-vous automatiquement au vaccin contre l'hépatite $B$ pour vos patients?
1) Jamais
2) Rarement
3) Habituellement
4) Toujours

9. Offrez-vous automatiquement le vaccin contre l'hépatite A aux patients atteints d'hépatite $B$ chronique qui sont séronégatifs pour les anticorps du VHA?
1) Jamais
2) Rarement
3) Habituellement
4) Toujours

10. Demandez-vous automatiquement à vos patients s'ils présentent des facteurs de risque d'hépatite $B$ ?
1) Jamais
2) Rarement
3) Habituellement
4) Toujours

11. Chez quel type de patients NE feriez-vous PAS automatiquement un test de dépistage pour l'hépatite B? (Choisissez toutes les réponses qui s'appliquent.)

1) Toute personne présentant des antécédents d'abus de substances prises par voie i.v.

2) Personne atteinte d'hépatite $C$

3) Toute personne qui a reçu une transfusion sanguine avant 1992

4) Toute personne venant d'un pays dont le taux de portage du VHB est $\geq 2 \%$

5) Toute femme enceinte

6) Les hommes qui ont des relations sexuelles avec d'autres hommes

Réponse correcte: 3

12. Quels trois tests de dépistage utiliseriez-vous pour déterminer si une personne est atteinte d'hépatite $B$ ?
1) ALT / AST
2) $\mathrm{AgHBs}$
3) anticorps anti-HBs
4) $\mathrm{AgHBe}$
5) anticorps anti-HBe
6) anticorps anti-HBc (total)
Réponse correcte: 2, 3, 6

13. Quelle est la signification des résultats sérologiques suivants?

\begin{tabular}{|l|c|c|c|}
\hline & $\begin{array}{c}\text { Immunité } \\
\text { en raison } \\
\text { d'un vaccin }\end{array}$ & $\begin{array}{c}\text { Infection } \\
\text { antérieure } \\
\text { par le virus } \\
\text { de } \\
\text { I'hépatite B }\end{array}$ & $\begin{array}{c}\text { Infection } \\
\text { active en } \\
\text { cours par le } \\
\text { virus de } \\
\text { I'hépatite B }\end{array}$ \\
\hline AgHbs+, anti-HBs-, anti-HBc+ & & & $x$ \\
\hline AgHBs-, anti-HBs+, anti-HBc+ & & $x$ & \\
\hline AgHBs-, anti-HBs+, anti-HBc- & $x$ & & \\
\hline
\end{tabular}

14. Un taux d'ALT normal signifie qu'il n'y a pas de maladie hépatique grave.
1) Vrai

2) Faux

Réponse correcte: 2 
15. La plupart des personnes atteintes de cirrhose sont asymptomatiques.
1) Vrai
2) Faux
Réponse correcte: 1

16. Une échographie abdominale normale signifie qu'il n'y a pas de cirrhose.

1) Vrai

2) Faux

Réponse correcte: 2

17. Voici les résultats d'un homme de 55 ans atteint d'hépatite B chronique :

ALT : 24

Plaquettes : 125

RNI : 1,0

Albumine : 40

Bilirubine : $17 \mu \mathrm{mol} / \mathrm{L}$

La probabilité qu'il présente une cirrhose est :

1) Faible

2) Modérée

3) Élevée

4) Je ne sais pas

Réponse correcte: 3

18. Pour quel type de patients atteints d'hépatite $B$ chronique feriez-vous régulièrement le dépistage du carcinome hépatocellulaire?

1) Toute personne recevant un traitement contre l'hépatite $B$

2) Toute personne âgée de $>50$ ans

3) Toute personne présentant un taux élevé de transaminases

4) Toute personne ayant une charge virale élevée

5) Toutes ces réponses

Réponse correcte: 2

19. Quel est le médicament le plus sécuritaire pour soulager la douleur chez un patient atteint de cirrhose?

1) Morphine

2) Acétaminophène

3) Ibuprofène

4) Codéine

5) Aucune de ces réponses

Réponse correcte: 2

20. Dirigeriez-vous cette patiente vers un spécialiste pour obtenir un traitement?

Femme de 24 ans

Plaquettes : 285

$\mathrm{AgHBe}+$

ADN du VHB : $9 \log \mathrm{UI} / \mathrm{mL}$

ALT : 24

1) Oui

2) Non

Réponse correcte: 2

21. Dirigeriez-vous ce patient vers un spécialiste pour obtenir un traitement?

Homme de 45 ans

Plaquettes : 145
AgHBe-

ADN du VHB : $5 \log \mathrm{UI} / \mathrm{mL}$

ALT : 43

1) Oui

2) Non

Réponse correcte: 1

22. Veuillez indiquer votre niveau de connaissance À L'HEURE ACTUELLE pour chacun des sujets suivants :

\begin{tabular}{|c|c|c|c|c|c|}
\hline \multirow[b]{2}{*}{ Sujet } & \multicolumn{5}{|c|}{ Faible................... Élevé } \\
\hline & 1 & 2 & 3 & 4 & 5 \\
\hline \multicolumn{6}{|l|}{ Identifier les facteurs de risque de l'hépatite B } \\
\hline \multicolumn{6}{|l|}{ Dépistage de l'hépatite B } \\
\hline \multicolumn{6}{|l|}{$\begin{array}{l}\text { Interpréter les résultats des tests de dépistage de } \\
\text { I'hépatite B }\end{array}$} \\
\hline \multicolumn{6}{|l|}{$\begin{array}{l}\text { Administrer un vaccin aux patients atteints } \\
\text { d'hépatite B }\end{array}$} \\
\hline \multicolumn{6}{|l|}{ Reconnaître la cirrhose } \\
\hline \multicolumn{6}{|l|}{ Prendre en charge un patient atteint de cirrhose } \\
\hline Dépistage du carcinome hépatocellulaire $(\mathrm{CHC})$ & & & & & \\
\hline
\end{tabular}

23. Veuillez indiquer le niveau de connaissance DÉSIRÉ pour chacun des sujets suivants :

\begin{tabular}{|c|c|c|c|c|}
\hline \multirow[b]{2}{*}{ Sujet } & \multicolumn{4}{|c|}{ Faible................... Élevé } \\
\hline & 12 & 3 & 4 & 5 \\
\hline \multicolumn{5}{|l|}{ Identifier les facteurs de risque de l'hépatite B } \\
\hline \multicolumn{5}{|l|}{ Dépistage de l'hépatite B } \\
\hline \multicolumn{5}{|l|}{$\begin{array}{l}\text { Interpréter les résultats des tests de dépistage de } \\
\text { l'hépatite B }\end{array}$} \\
\hline \multicolumn{5}{|l|}{$\begin{array}{l}\text { Administrer un vaccin aux patients atteints } \\
\text { d'hépatite B }\end{array}$} \\
\hline \multicolumn{5}{|l|}{ Reconnaître la cirrhose } \\
\hline \multicolumn{5}{|l|}{ Prendre en charge un patient atteint de cirrhose } \\
\hline Dépistage du carcinome hépatocellulaire $(\mathrm{CHC})$ & & & & \\
\hline
\end{tabular}

24. Selon vous, quelle est la meilleure source d'information pour approfondir vos connaissances sur l'hépatite B?
1) Revues
2) Livres
3) Ressources en ligne
4) Conférences
5) Autre

\section{REFERENCES}

1. Lavanchy D. Hepatitis B virus epidemiology, disease burden, treatment, and current and emerging prevention and control measures. J Viral Hepat 2004;11:97-107.

2. Parkin DM. The global health burden of infection-associated cancers in the year 2002. Int J Cancer 2006;118:3030-44.

3. Mast EE, Margolis HS, Fiore AE, et al. A comprehensive immunization strategy to eliminate transmission of hepatitis B virus infection in the United States: Recommendations of the Advisory Committee on Immunization Practices (ACIP) part 1: Immunization of infants, children, and adolescents. MMWR Recomm Rep 2005;54:1-31.

4. Lok AS, McMahon BJ. Chronic hepatitis B. Hepatology 2007;45:507-39.

5. Llovet JM, Burroughs A, Bruix J. Hepatocellular carcinoma. Lancet 2003;362:1907-17.

6. Lai CJ, Nguyen TT, Hwang J, et al. Provider knowledge and practice regarding hepatitis B screening in Chinese-speaking patients. J Cancer Educ 2007;22:37-41.

7. Ferrante JM, Winston DG, Chen PH, et al. Family physicians' knowledge and screening of chronic hepatitis and liver cancer. Fam Med 2008;40:345-51. 
8. Peksen Y, Canbaz S, Leblebicioglu H, et al. Primary care physicians' approach to diagnosis and treatment of hepatitis $\mathrm{B}$ and hepatitis $\mathrm{C}$ patients. BMC Gastroenterol 2004:4:3.

9. Tsai N. Diagnosis and management of chronic hepatitis B in the primary care setting. Postgrad Med 2006;119:28-36.

10. Sherman M, Shafran S, Burak K, et al. Management of chronic hepatitis B: Consensus guidelines. Can J Gastroenterol 2007;21(Suppl C):5C-24C.

11. Canadian Resident Match Service (CaRMS). 2007-2008 Family Medicine Comparison. < http://www.carms.ca/eng/operations_ R1reports_08_e.shtml> (Accessed on October 27, 2009).

12. NIH consensus development statement on management of hepatitis B. NIH Consens State Sci Statements 2008;25:1-29.

13. Weinbaum CM, Williams I, Mast EE, et al. Recommendations for identification and public health management of persons with chronic hepatitis B virus infection. MMWR Recomm Rep 2008;57:1-20.

14. Garcia-Tsao G, Parikh CR, Viola A. Acute kidney injury in cirrhosis. Hepatology 2008;48:2064-77.

15. Worobetz LJ. Hepatic encephalopathy. In: Thomson ABR, Shaffer EA, eds. First Principles of Gastroenterology: The Basis of Disease and an Approach to Management, 5th edn. Janssen-Ortho. $<$ http://www.cag-acg.org/uploads/firstprinciples/english.html> (Accessed on October 27, 2009).
16. Fendrick AM, Hirth RA, Chernew ME. Differences between generalist and specialist physicians regarding Helicobacter pylori and peptic ulcer disease. Am J Gastroenterol 1996;91:1544-8.

17. James PA, Cowan TM, Graham RP, et al. Family physicians' attitudes about and use of clinical practice guidelines. J Fam Pract 1997;45:341-7.

18. Shehab TM, Sonnad SS, Lok AS. Management of hepatitis C patients by primary care physicians in the USA: Results of a national survey. J Viral Hepat 2001;8:377-83.

19. Coppola AG, Karakousis PC, Metz DC, et al. Hepatitis C knowledge among primary care residents: Is our teaching adequate for the times? Am J Gastroenterol 2004;99:1720-5.

20. Shehab TM, Sonnad SS, Jeffries M, et al. Current practice patterns of primary care physicians in the management of patients with hepatitis C. Hepatology 1999;30:794-800.

21. Keeffe EB, Dieterich DT, Han SH, et al. A treatment algorithm for the management of chronic hepatitis $B$ virus infection in the United States: 2008 update. Clin Gastroenterol Hepatol 2008;6:1315-41.

22. Pinette GD Cox JJ, Heathcote J, Moore L, et al. Primary Care Management of Hepatitis C: Professional Desk Reference 2009. $<$ www.phac-aspc.gc.ca/hepc/pubs/pdf/hepc_guide-eng.pdf>. (Accessed on October 27, 2009). 


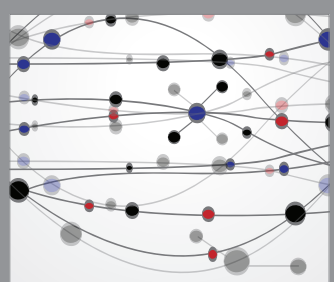

The Scientific World Journal
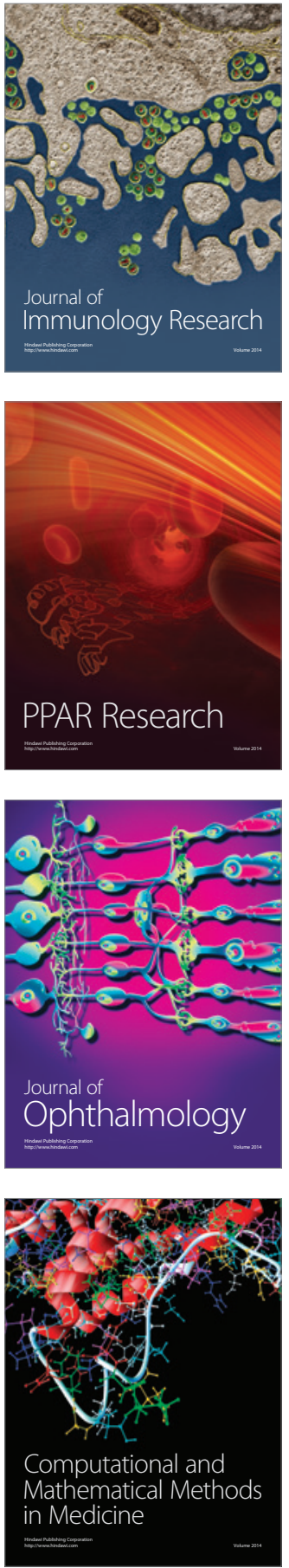

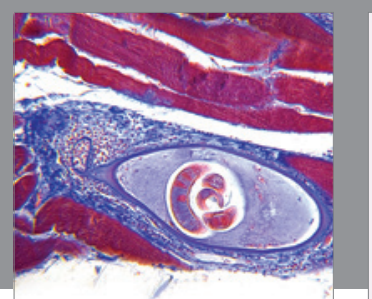

Gastroenterology Research and Practice

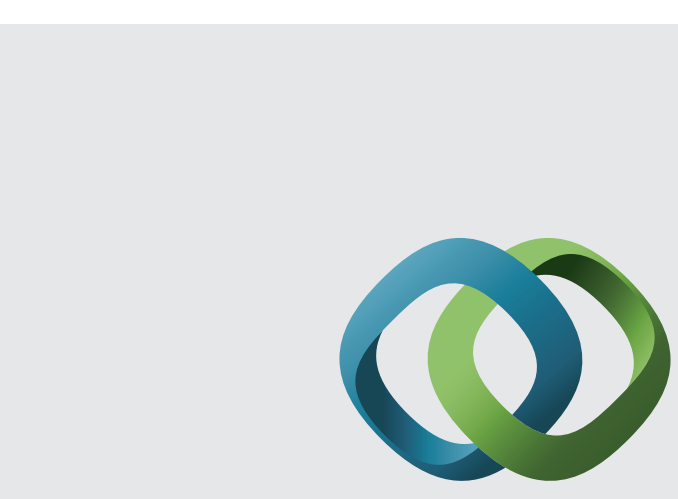

\section{Hindawi}

Submit your manuscripts at

http://www.hindawi.com
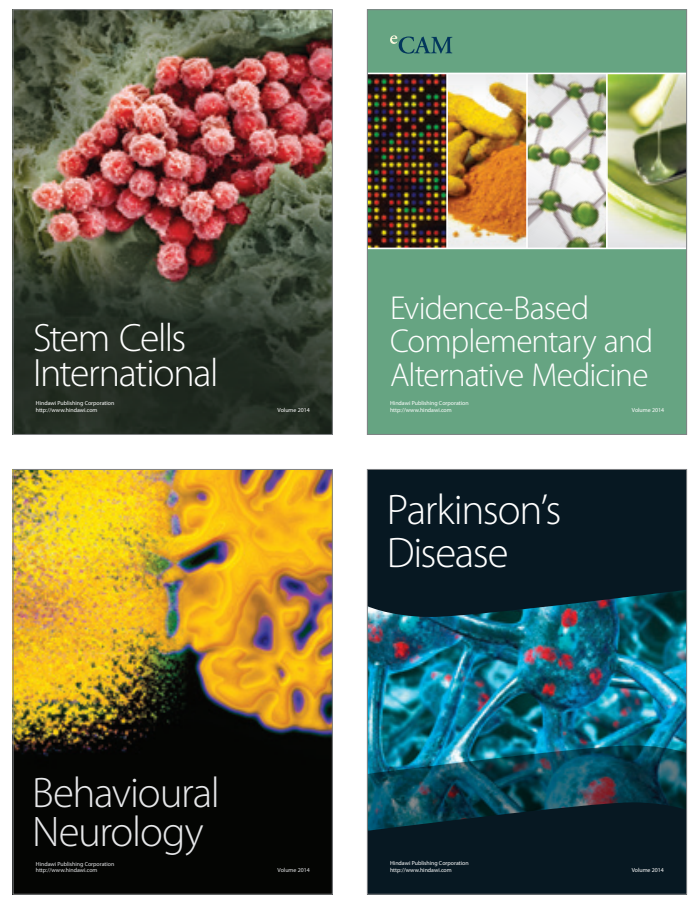
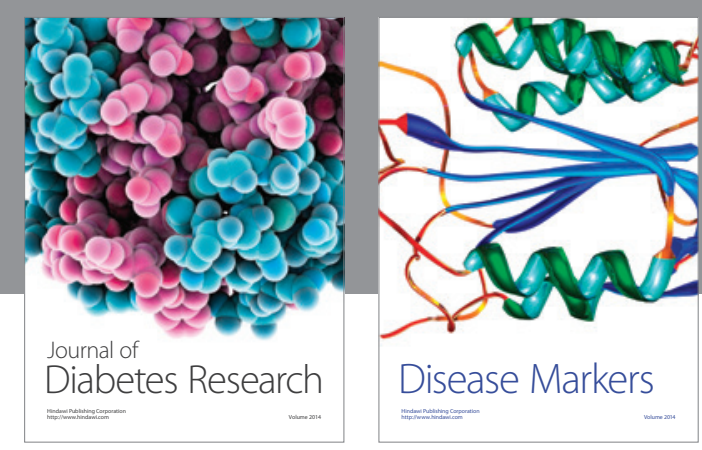

Disease Markers
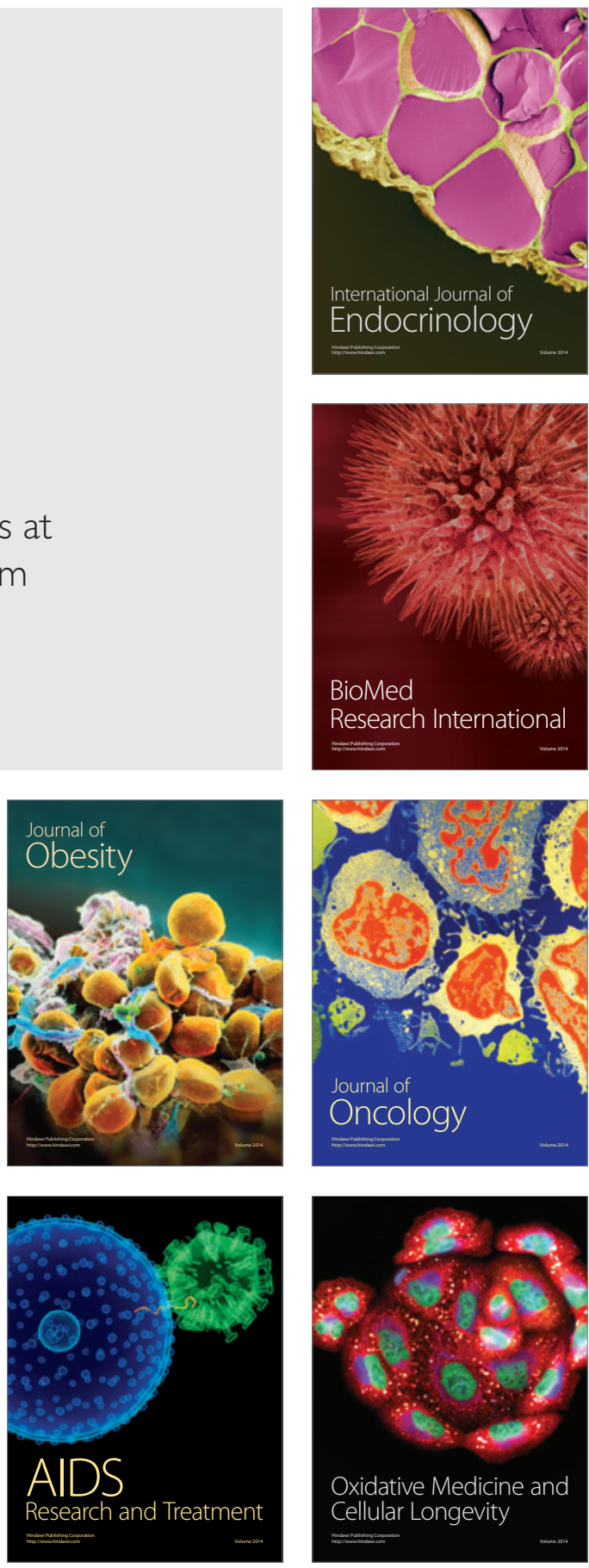